\title{
Accused and prosecutor: The importance of a trial
}

\author{
Andrea Montisci, MD, ${ }^{\mathrm{a}}$ and Antonio Miceli, $\mathrm{MD}, \mathrm{PhD}^{\mathrm{a}, \mathrm{b}}$
}

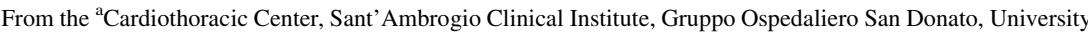
and Research Hospitals, Milan, Italy; and the ${ }^{\mathrm{b}}$ Department of Clinical Science at South Bristol, University of Bristol, Bristol, United Kingdom.

Disclosures: Miceli is a consultant for Livanova. Montisci has nothing to disclose with regard to commercial support.

Received for publication Sept 18, 2017; accepted for publication Sept 22, 2017; available ahead of print Nov 7 , 2017.

Address for reprints: Antonio Miceli, MD, PhD, Cardiothoracic Center, Istituto Clinico Sant'Ambrogio, Gruppo

Ospedaliero San Donato, Via Giuseppe Faravelli, 1620149 Milan, Italy (E-mail: antoniomiceli79@alice.it).

J Thorac Cardiovasc Surg 2018;155:e119-20

$0022-5223 / \$ 36.00$

Copyright (C) 2017 by The American Association for Thoracic Surgery

https://doi.org/10.1016/j.jtcvs.2017.09.108
}

Leukemoid reaction, commonly defined as a rise in white blood cell count beyond 30,000 cells $/ \mu \mathrm{L}$, is a rare finding after cardiac surgery, with only sparse reports. ${ }^{2,3}$ In unselected populations, leukemoid reactions are associated with a high morbidity rate and a high mortality, ${ }^{1}$ and systemic infections and myeloproliferative disorders are often identified as causative factors. In this issue of the Journal, Ellison and colleagues ${ }^{4}$ highlight the importance of recognizing a leukemoid reaction after cardiac surgery to reduce the potential risks associated with unnecessary prolonged treatments. Even though leukemoid reaction is a rare event in cardiac surgery, this case report has the merit of bringing to our attention the pivotal question of inflammation in cardiac surgery. Surgical trauma, cardiopulmonary bypass, cardiac ischemia, active endocarditis, and chronic heart failure are all conditions well known to be able to trigger systemic inflammation, ${ }^{5,6}$ potentially associated with increased morbidity and mortality. ${ }^{7}$ When faced with these clinical issues, we have to be aware that our diagnostic power is poor and the therapies are limited. In the last years, much epidemiologic and clinical attention has been addressed to systemic inflammatory response syndrome. As recently questioned, however, the definition of systemic inflammatory response syndrome lacks specificity, ${ }^{8,9}$ and it is no longer used to define sepsis. ${ }^{10}$

Many cardiac surgical patients who satisfy diagnostic criteria for systemic inflammatory response syndrome often undergo an uneventful postoperative course. ${ }^{11}$ This is even more true when we rely on common clinical markers, as white blood cell count or C-reactive protein level, to determine the degree of inflammation. The low specificity of these definitions might lead to misdiagnosis and overtreatment, with the known detrimental consequences of antibiotic misuse. Nevertheless, in clinical situations such as chronic heart failure, ${ }^{12}$ in which a self-perpetuating and dysregulated inflammatory process takes place, our therapeutic panel is narrow and limited. Effective therapies specifically addressing the inflammatory process are lacking

\section{References} 232-44.

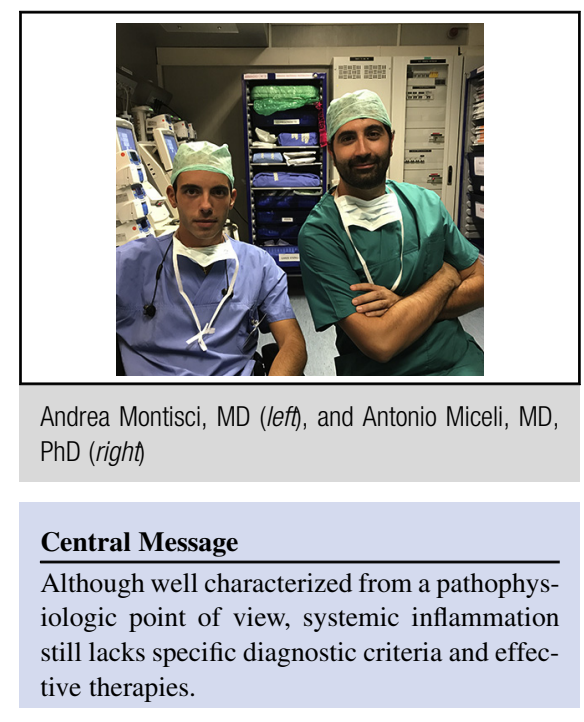

See Article page e117.

because of multiple failures in randomized, controlled trials. Statins have been proposed as a potential treatment option to mitigate dysregulated inflammatory states, but their utility has not been confirmed in clinical trials. ${ }^{13}$ Moreover, 2 recent large, randomized, controlled trials heavily questioned the usefulness of corticosteroids during cardiopulmonary bypass. ${ }^{14,15}$ Among new therapies, cytokine absorption seems to be the most promising option, whether used intraoperatively or postoperatively in selected cases. $^{16-18}$ The evidence is growing, and the expectations are high: we know the accused (inflammation), but we are still trying to put it on trial!

1. Potasman I, Grupper M. Leukemoid reaction: spectrum and prognosis of 173 adult patients. Clin Infect Dis. 2013;57:e177-81.

2. Padmakumar G, Ravikrishnan J, Jayakumar P, Prasad K. Leukemoid like reaction in a post CABG patient. Indian J Anaesth. 2014;58:315-8.

3. Drury NE, Ali A, Mussa S, Webb ST, Rege KP, Wallwork J. Acute leukaemoid reaction following cardiac surgery. J Cardiothorac Surg. 2007;2:3.

4. Ellison TA, Mandal K. Leukemoid reaction: case report. J Thorac Cardiovasc Surg. 2018;155:e117-8.

5. Paparella D, Yau TM, Young E. Cardiopulmonary bypass induced inflammation: pathophysiology and treatment. An update. Eur J Cardiothorac Surg. 2002;21:

6. Hirai S. Systemic inflammatory response syndrome after cardiac surgery under cardiopulmonary bypass. Ann Thorac Cardiovasc Surg. 2003;9:365-70.

7. Allan CK, Newburger JW, McGrath E, Elder J, Psoinos C, Laussen PC, et al. The relationship between inflammatory activation and clinical outcome after infant cardiopulmonary bypass. Anesth Analg. 2010;111:1244-51.

8. Depuydt PO, Kress JP, Salluh JI. The ten "diseases" that are not true diseases. Intensive Care Med. 2016;42:411-4

9. Semler MW, Wheeler AP. Systemic inflammatory response syndrome after cardiac surgery: time for a change. Chest. 2014;145:1181-2. 
10. Singer M, Deutschman CS, Seymour CW, Shankar-Hari M, Annane D, Bauer M, et al. The Third International Consensus Definitions for Sepsis and Septic Shock (Sepsis-3). JAMA. 2016;315:801-10.

11. MacCallum NS, Finney SJ, Gordon SE, Quinlan GJ, Evans TW. Modified criteria for the systemic inflammatory response syndrome improves their utility following cardiac surgery. Chest. 2014;145:1197-203.

12. Zhang Y, Bauersachs J, Langer HF. Immune mechanisms in heart failure. Eur J Heart Fail. September 11, 2017 [Epub ahead of print].

13. Sodha NR, Sellke FW. The effect of statins on perioperative inflammation in cardiac and thoracic surgery. J Thorac Cardiovasc Surg. 2015;149:1495-501.

14. Whitlock RP, Devereaux PJ, Teoh KH, Lamy A, Vincent J, Pogue J, et al. Methylprednisolone in patients undergoing cardiopulmonary bypass (SIRS): a randomised, double-blind, placebo-controlled trial. Lancet. 2015;386:1243-53.
15. Dieleman JM, de Wit GA, Nierich AP, Rosseel PM, van der Maaten JM, Hofland J, et al; DExamethasone for Cardiac Surgery (DECS) Study Group. Long-term outcomes and cost effectiveness of high-dose dexamethasone for cardiac surgery: a randomised trial. Anaesthesia. 2017;72:704-13.

16. Träger K, Fritzler D, Fischer G, Schröder J, Skrabal C, Liebold A, et al. Treatment of post-cardiopulmonary bypass SIRS by hemoadsorption: a case series. Int J Artif Organs. 2016;39:141-6.

17. Träger K, Skrabal C, Fischer G, Datzmann T, Schroeder J, Fritzler D, et al. Hemoadsorption treatment of patients with acute infective endocarditis during surgery with cardiopulmonary bypass - a case series. Int J Artif Organs. 2017;40:240-9.

18. Baumann A, Buchwald D, Annecke T, Hellmich M, Zahn PK, Hohn A. RECCAS - REmoval of Cytokines during CArdiac Surgery: study protocol for a randomised controlled trial. Trials. 2016;17:137. 